\title{
FAKTOR-FAKTOR YANG MEMPENGARUHI STRUKTUR MODAL PADA SEKTOR PERKEBUNAN
}

\author{
JULIANA YAPI \\ SATRIYO WIBOWO \\ Trisakti School of Management, JI. Kyai Tapa No. 20 Jakarta 11440, Indonesia \\ julianayapithe@yahoo.co.id
}

\begin{abstract}
The purpose of this research is to test and analyze empirically the influence of profitability, firm size, liquidity, business risk, sales growth, asset structure and growth asset to capital structure. This research data consists of financial statements of plantation sector companies in Indonesia that listed in Indonesia Stock Exchange period 2008-2016. Sampling technique is used purposive sampling with 8 companies that met the criteria and were analyzed using panel data regression techniques with fixed effect model by using software Eviews 9 to test the hyphotesis. The results of this research shows that profitability, size, liquidity, business risk, and asset structure influence the capital structure, while sales growth and growth asset do not influence the capital structure. Where overall this model is fit.
\end{abstract}

Keywords: Profitability, size, liquidity, business risk, sales growth, asset structure, growth asset, capital structure

Abstrak: Tujuan penelitian adalah untuk menguji dan menganalisis secara empiris hubungan pengaruh dari profitabilitas, ukuran perusahaan, likuiditas, risiko bisnis, pertumbuhan penjualan, struktur aset dan pertumbuhan aset terhadap struktur modal. Data penelitian ini terdiri dari laporan keuangan perusahaan perkebunan di Indonesia yang terdaftar di Bursa Efek Indonesia periode 2008 sampai 2016. Teknik pengumpulan sampel yang digunakan adalah purposive sampling dengan 8 perusahaan yang memenuhi kriteria dan dianalisis menggunakan teknik regresi data panel dengan model fixed effect dalam meguji hipotesis dengan menggunakan software Eviews 9 . Hasil penelitian ini menunjukkan bahwa profitabilitas, ukuran perusahaan, likuiditas, risiko bisnis dan struktur aset mempengaruhi struktur modal, sementara pertumbuhan penjualan dan pertumbuhan aset tidak mempengaruhi struktur modal. Dimana secara keseluruhan model ini dinyatakan fit.

Kata kunci: Profitabilitas, ukuran perusahaan, likuiditas, risiko bisnis, pertumbuhan penjualan, struktur aset, pertumbuhan aset, struktur modal.

\section{PENDAHULUAN}

Dalam menghadapi persaingan usaha yang semakin ketat, sebuah perusahaan yang didirikan harus memiliki suatu tujuan agar perusahaan dapat terus beroperasi dalam jangka panjang. Tujuan perusahaan yakni mencapai laba yang maksimum sehingga dapat mensejahterakan para pemegang saham dan meningkatkan nilai perusahaan. Suatu tujuan akan tercapai apabila perusahaan dikelola dengan baik sesuai dengan harapan yang telah ditetapkan oleh perusahaan. Tujuan perusahaan tidak akan tercapai apabila perusahaan tidak dapat mengelola modal kerja sebagai penunjang yang digunakan dalam penganggaran struktur modal. 
Kebijakan perusahaan untuk mencapai tujuan perusahaan tersebut tidak lepas pada permasalahan seberapa besar perusahaan dapat memenuhi kebutuhan pendanaan atau permodalan perusahaan. Pendanaan tersebut dapat berasal dari internal perusahaan yang berupa laba di tahan serta depresiasi sedangkan eksternal perusahaan berupa dana yang berasal dari para kreditur, pemegang surat utang (bondholders) dan pemilik perusahaan Keputusan pendanaan perusahaan yang baik dapat dilihat dari struktur modalnya, yakni dalam keputusan keuangan yang berkaitan dengan komposisi hutang, baik hutang jangka pendek permanen, hutang jangka panjang, saham preferen, dan saham biasa yang akan digunakan oleh perusahaan (Sartono 2010, 225) dalam Juliantika dan Dewi (2016).

$\begin{array}{ccr}\text { Struktur } & \text { modal } & \text { merupakan } \\ \text { pembelanjaan } & \text { permanen } & \text { dimana }\end{array}$ mencerminkan perimbangan antara hutang jangka panjang dengan modal sendiri (Riyanto 2011, 22) dalam Juliantika dan Dewi (2016). Cornett et al. $(2015,37)$ menyatakan bahwa "Capital structure is the amount of debt versus equity financing held on the balance sheet because it can determine whether the firm stays in business or goes bankrupt." Dari pernyataan di atas menunujukkan bahwa struktur modal merupakan perimbangan antara hutang dengan ekuitas dan merupakan hal yang penting bagi suatu perusahaan karena dari penyusunan struktur modal yang baik akan mempengaruhi kinerja dan hasil keberlangsungan hidup perusahaan itu sendiri atau sebaliknya.

Keputusan pendanaan atau struktur modal yang tidak cermat akan berpengaruh langsung terhadap penurunan profitabilitas perusahaan tersebut. Keputusan struktur modal yang diambil oleh manajer tidak hanya berpengaruh terhadap profitabilitas perusahaan, tetapi keputusan pendanaan atau struktur modal secara langsung dapat berpengaruh terhadap besarnya risiko yang ditanggung pemegang saham serta besarnya tingkat pengembalian atau tingkat keuntungan yang diharapkan (Brigham dan Houston 2006, 17) dalam Juliantika dan Dewi (2016).

Perusahaan dengan tingkat profitabilitas yang tinggi akan meningkatkan daya saing perusahaan sehingga dapat membuat investor mau menanamkan dananya pada perusahaan. Sesuai dengan pecking order theory, perusahaan yang profitable umumnya meminjam dalam jumlah yang sedikit. Hal tersebut bukan disebabkan karena perusahaan mempunyai target debt ratio yang rendah, tetapi karena perusahaan mempunyai internal financing yang lebih banyak dan hanya memerlukan external financing yang sedikit. Perusahaan yang kurang profitable akan cenderung mempunyai hutang yang lebih besar karena dua alasan, yaitu dana internal tidak cukup, dan hutang merupakan sumber eksternal yang lebih disukai (Husnan 1996, 324) dalam Juliantika dan Dewi (2016).

Banyak faktor yang mempengaruhi keputusan manajer dalam menentukan struktur modal perusahaan diantaranya seperti profitabilitas, ukuran perusahaan, likuiditas, risiko bisnis, pertumbuhan penjualan, struktur aset dan pertumbuhan aset, dan faktor lainnya. Profitabilitas merupakan kemampuan perusahaan mendapatkan laba melalui semua kemampuan dan sumber yang ada seperti kegiatan penjualan, kas, modal, jumlah karyawan, jumlah cabang, dan sebagainya (Harahap 1011, 304) dalam Juliantika dan Dewi (2016). Perusahaan selalu menginginkan tingkat profitabilitas yang tinggi. Dari profit yang ada, perusahaan dapat mengalokasikannya kedalam bentuk laba ditahan ataupun melakukan ekspansi usaha. Menurut hasil penelitian Sheikh (2011), Sabir (2012), Fauzi (2013), Alzomaia (2014), Umer (2014) dalam Juliantika dan Dewi (2016) yang menyatakan bahwa profitabilitas berpengaruh negatif terhadap struktur modal. Menurut hasil penelitian yang dilakukan oleh Diane (2008) dan Juniati (2010) dalam Juliantika dan Dewi (2016) yang menyatakan bahwa 
profitabilitas tidak berpengaruh terhadap struktur modal. Hasil penelitian yang berbeda ditunjukkan oleh Salehi (2012) dan Saleem (2013) dalam Juliantika dan Dewi (2016) yang menyatakan bahwa profitabilitas berpengaruh positif terhadap struktur modal.

Ukuran perusahaan menggambarkan besar kecilnya suatu perusahaan dimana perusahaan yang besar akan lebih mudah mendapatkan pinjaman dari luar baik dalam bentuk hutang maupun modal saham karena biasanya perusahaan besar disertai dengan reputasi yang cukup baik di mata masyarakat (Sartono 2010, 249) dalam Juliantika dan Dewi (2016). Menurut penelitian yang yang dilakukan oleh Akinlo (2011), AL- Shubiri (2010), Parlak (2010), Ahmed (2010), serta Sheikh (2011) dalam Juliantika dan Dewi (2016) yang menyatakan bahwa ukuran perusahaan berpengaruh positif terhadap struktur modal. Namun hasil penelitian yang berbeda ditunjukkan oleh Lim (2014), AL- Shubiri (2010), Utami (2009) dalam Juliantika dan Dewi (2016) yang menyatakan bahwa ukuran perusahaan berpengaruh negatif terhadap struktur modal.

Likuiditas yang merupakan kemampuan perusahaan untuk memenuhi kewajiban finansialnya dalam jangka pendek dengan dana lancar yang tersedia (Kasmir 2009, 129) dalam Juliantika dan Dewi (2016). Likuiditas berguna untuk dapat mengetahui kemampuannya dalam membiayai dan memenuhi kewajiban atau hutang pada saat ditagih atau pada saat jatuh tempo (Kasmir 2011, 145) dalam Juliantika dan Dewi (2016). Menurut penelitian yang dilakukan oleh Kühnhausen (2014), AL- Shubiri (2010), Ramlall (2009), Verena dan Haryanto (2013), Sheikh dan Zongjun (2011) dalam Juliantika dan Dewi (2016) yang menyatakan bahwa likuiditas berpengaruh yang negatif terhadap struktur modal. Hasil penelitian yang berbeda oleh Sheikh (2011), Umer (2014), dan Akinlo (2011) dalam Juliantika dan Dewi (2016) yang menyatakan bahwa likuiditas berpengaruh positif terhadap struktur modal.
Risiko bisnis yang merupakan salah satu risiko yang dihadapi oleh perusahaan ketika menjalankan kegiatan operasinya, yaitu kemungkinan ketidakmampuan perusahaan untuk membiayai kegiatan operasionalnya (Gitman 2003, 215) dalam Juliantika dan Dewi (2016). Risiko timbul seiring dengan munculnya beban biaya atas pinjaman yang dilakukan perusahaan. Semakin besar beban biaya yang harus ditanggung maka semakin risiko yang dihadapi perusahaan juga semakin besar. Menurut hasil penelitian yang dilakukan oleh Handayani (2011), Alzomaia (2014), AL- Shubiri (2010), Parlak (2010), Ahmed (2010) dalam Juliantika dan Dewi (2016) yang menyatakan bahwa risiko bisnis berpengaruh yang negatif terhadap struktur modal. Hasil penelitian berbeda ditunjukkan oleh Seftianne dan Handayani (2011), Wimelda dan Marlinah (2013) serta Memon (2012) dalam Juliantika dan Dewi (2016) yang menyatakan bahwa risiko bisnis berpengaruh positif terhadap struktur modal.

Pertumbuhan penjualan adalah perhitungan kenaikan dan penurunan penjualan perusahaan dari tahun ke tahun. Perusahaan dengan penjualan yang relatif stabil dapat lebih aman memperoleh lebih banyak pinjaman dan beban tetap lebih tinggi daripada perusahaan yang penjualannya tidak stabil (Brigham dan Houston 2011, 39) dalam Darya dan Maesroh (2016). Sebagian besar perusahaan mencari dana dengan memanfaatkan peluang pertumbuhan tersebut. Perusahaan dengan penjualan yang stabil dapat lebih banyak mengambil hutang dan dapat menanggung biaya tetap yang tinggi dibandingkan perusahaan yang penjualannya tidak stabil.

Struktur aset $m$ erupakan proporsi atau rasio antara aset tetap terhadap total aset. Total aset adalah jumlah semua aset perusahaan terdiri dari aset tetap, aset lancar dan aset lainnya yang nilainya seimbang antara total kewajiban dengan ekuitas (Margaretha 2003, 108) dalam Darya dan Maesroh (2016). Struktur aset merupakan salah satu faktor penting dalam 
struktur modal atau keputusan pembiayaan perusahaan, karena jika perusahaan sedang mengalami kesulitan dalam membayar hutang, aset perusahaan dapat digunakan sebagai jaminan yang dapat mengurangi risiko kebangkrutan perusahaan.

Pertumbuhan aset merupakan selisih antara jumlah aset periode ini dengan periode sebelumnya dibandingkan dengan aset periode sebelumnya. Perusahaan yang memiliki tingkat pertumbuhan tinggi membutuhkan pendanaan yang lebih tinggi untuk ekspansi bisnis di masa depan. Perusahaan dengan tingkat pertumbuhan tinggi cenderung akan menggunakan hutang dibanding menggunakan ekuitas (Brigham dan Houston 1996, 39) dalan Darya dan Maesroh (2016).

Berbagai penelitian telah dilakukan mengenai struktur modal, namun demikian terdapat perbedaan hasil penelitian mengenai variabel independen berpengaruh positif, negatif, ataupun tidak berpengaruh terhadap variabel dependen. Kesenjangan tersebut di atas yang akan dibuktikan dalam penelitian ini.

Berdasarkan research gap pada hasil penelitianpenelitian sebelumnya, maka penelitian ini perlu dikaji kembali untuk memperjelas temuan selanjutnya. Peneliti tertarik untuk meneliti kembali Faktor-Faktor yang Mempengaruhi Struktur Modal pada Sektor Perkebunan Periode 2008-2016.

\section{METODE PENELITIAN}

Dalam menghadapi persaingan usaha yang semakin ketat, sebuah perusahaan yang didirikan harus memiliki suatu tujuan agar perusahaan dapat terus beroperasi dalam jangka panjang. Tujuan perusahaan yakni mencapai laba yang maksimum sehingga dapat mensejahterakan para pemegang saham dan meningkatkan nilai perusahaan. Suatu tujuan akan tercapai apabila perusahaan dikelola dengan baik sesuai dengan harapan yang telah ditetapkan oleh perusahaan. Tujuan perusahaan tidak akan tercapai apabila perusahaan tidak dapat mengelola modal kerja sebagai penunjang yang digunakan dalam penganggaran struktur modal.

Kebijakan perusahaan untuk mencapai tujuan perusahaan tersebut tidak lepas pada permasalahan seberapa besar perusahaan dapat memenuhi kebutuhan pendanaan atau permodalan perusahaan. Pendanaan tersebut dapat berasal dari internal perusahaan yang berupa laba di tahan serta depresiasi sedangkan eksternal perusahaan berupa dana yang berasal dari para kreditur, pemegang surat utang (bondholders) dan pemilik perusahaan (Gitman 2003, 15) dalam Juliantika dan Dewi (2016). Keputusan pendanaan perusahaan yang baik dapat dilihat dari struktur modalnya, yakni dalam keputusan keuangan yang berkaitan dengan komposisi hutang, baik hutang jangka pendek permanen, hutang jangka panjang, saham preferen, dan saham biasa yang akan digunakan oleh perusahaan (Sartono 2010, 225) dalam Juliantika dan Dewi (2016).

$$
\text { Struktur modal merupakan }
$$

pembelanjaan permanen dimana

mencerminkan perimbangan antara hutang jangka panjang dengan modal sendiri menurut Juliantika dan Dewi (2016). Cornett et al. (2015, 37) menyatakan bahwa "Capital structure is the amount of debt versus equity financing held on the balance sheet because it can determine whether the firm stays in business or goes bankrupt." Dari pernyataan di atas menunujukkan bahwa struktur modal merupakan perimbangan antara hutang dengan ekuitas dan merupakan hal yang penting bagi suatu perusahaan karena dari penyusunan struktur modal yang baik akan mempengaruhi kinerja dan hasil keberlangsungan hidup perusahaan itu sendiri atau sebaliknya.

Keputusan pendanaan atau struktur modal yang tidak cermat akan berpengaruh langsung terhadap penurunan profitabilitas perusahaan tersebut. Keputusan struktur modal yang diambil oleh manajer tidak hanya 
berpengaruh terhadap profitabilitas perusahaan, tetapi keputusan pendanaan atau struktur modal secara langsung dapat berpengaruh terhadap besarnya risiko yang ditanggung pemegang saham serta besarnya tingkat pengembalian atau tingkat keuntungan yang diharapkan (Brigham dan Houston 2006, 17) dalam Juliantika dan Dewi (2016).

Perusahaan dengan tingkat profitabilitas yang tinggi akan meningkatkan daya saing perusahaan sehingga dapat membuat investor mau menanamkan dananya pada perusahaan. Sesuai dengan pecking order theory, perusahaan yang profitable umumnya meminjam dalam jumlah yang sedikit. Hal tersebut bukan disebabkan karena perusahaan mempunyai target debt ratio yang rendah, tetapi karena perusahaan mempunyai internal financing yang lebih banyak dan hanya memerlukan external financing yang sedikit. Perusahaan yang kurang profitable akan cenderung mempunyai hutang yang lebih besar karena dua alasan, yaitu dana internal tidak cukup, dan hutang merupakan sumber eksternal yang lebih disukai (Husnan 1996, 324) dalam Juliantika dan Dewi (2016). Banyak faktor yang mempengaruhi keputusan manajer dalam menentukan struktur modal perusahaan diantaranya seperti profitabilitas, ukuran perusahaan, likuiditas, risiko bisnis, pertumbuhan penjualan, struktur aset dan pertumbuhan aset, dan faktor lainnya.

Profitabilitas merupakan kemampuan perusahaan mendapatkan laba melalui semua kemampuan dan sumber yang ada seperti kegiatan penjualan, kas, modal, jumlah karyawan, jumlah cabang, dan sebagainya (Harahap 1011, 304) dalam Juliantika dan Dewi (2016). Perusahaan selalu menginginkan tingkat profitabilitas yang tinggi. Dari profit yang ada, perusahaan dapat mengalokasikannya kedalam bentuk laba ditahan ataupun melakukan ekspansi usaha. Menurut hasil penelitian Sheikh (2011), Sabir (2012), Fauzi (2013), Alzomaia (2014), Umer (2014) dalam Juliantika dan Dewi (2016) yang menyatakan bahwa profitabilitas berpengaruh negatif terhadap struktur modal. Menurut hasil penelitian yang dilakukan oleh Diane (2008) dan Juniati (2010) dalam Juliantika dan Dewi (2016) yang menyatakan bahwa profitabilitas tidak berpengaruh terhadap struktur modal. Hasil penelitian yang berbeda ditunjukkan oleh Salehi (2012) dan Saleem (2013) dalam Juliantika dan Dewi (2016) yang menyatakan bahwa profitabilitas berpengaruh positif terhadap struktur modal.

Ukuran perusahaan menggambarkan besar kecilnya suatu perusahaan dimana perusahaan yang besar akan lebih mudah mendapatkan pinjaman dari luar baik dalam bentuk hutang maupun modal saham karena biasanya perusahaan besar disertai dengan reputasi yang cukup baik di mata masyarakat (Sartono 2010, 249) dalam Juliantika dan Dewi (2016). Menurut penelitian yang yang dilakukan oleh Akinlo (2011), AL- Shubiri (2010), Parlak (2010), Ahmed (2010), serta Sheikh (2011) dalam Juliantika dan Dewi (2016) yang menyatakan bahwa ukuran perusahaan berpengaruh positif terhadap struktur modal. Namun hasil penelitian yang berbeda ditunjukkan oleh Lim (2014), AL- Shubiri (2010), Utami (2009) dalam Juliantika dan Dewi (2016) yang menyatakan bahwa ukuran perusahaan berpengaruh negatif terhadap struktur modal.

Likuiditas yang merupakan kemampuan perusahaan untuk memenuhi kewajiban finansialnya dalam jangka pendek dengan dana lancar yang tersedia (Kasmir 2009, 129) dalam Juliantika dan Dewi (2016). Likuiditas berguna untuk dapat mengetahui kemampuannya dalam membiayai dan memenuhi kewajiban atau hutang pada saat ditagih atau pada saat jatuh tempo (Kasmir 2011, 145) dalam Juliantika dan Dewi (2016). Menurut penelitian yang dilakukan oleh Kühnhausen (2014), AL- Shubiri (2010), Ramlall (2009), Verena dan Haryanto (2013), Sheikh dan Zongjun (2011) dalam Juliantika dan Dewi (2016) yang menyatakan bahwa likuiditas berpengaruh yang negatif terhadap struktur modal. Hasil penelitian yang berbeda oleh Sheikh (2011), Umer (2014), dan Akinlo (2011) 
dalam Juliantika dan Dewi (2016) yang menyatakan bahwa likuiditas berpengaruh positif terhadap struktur modal.

Risiko bisnis yang merupakan salah satu risiko yang dihadapi oleh perusahaan ketika menjalankan kegiatan operasinya, yaitu kemungkinan ketidakmampuan perusahaan untuk membiayai kegiatan operasionalnya menurut Juliantika dan Dewi (2016). Risiko timbul seiring dengan munculnya beban biaya atas pinjaman yang dilakukan perusahaan. Semakin besar beban biaya yang harus ditanggung maka semakin risiko yang dihadapi perusahaan juga semakin besar. Menurut hasil penelitian yang dilakukan oleh Handayani (2011), Alzomaia (2014), AL- Shubiri (2010), Parlak (2010), Ahmed (2010) dalam Juliantika dan Dewi (2016) yang menyatakan bahwa risiko bisnis berpengaruh yang negatif terhadap struktur modal. Hasil penelitian berbeda ditunjukkan oleh Seftianne dan Handayani (2011), Juliantika dan Dewi (2016) yang menyatakan bahwa risiko bisnis berpengaruh positif terhadap struktur modal.

Pertumbuhan penjualan adalah perhitungan kenaikan dan penurunan penjualan perusahaan dari tahun ke tahun. Perusahaan dengan penjualan yang relatif stabil dapat lebih aman memperoleh lebih banyak pinjaman dan beban tetap lebih tinggi daripada perusahaan yang penjualannya tidak stabil (Brigham dan Houston 2011, 39) dalam Darya dan Maesroh (2016). Sebagian besar perusahaan mencari dana dengan memanfaatkan peluang pertumbuhan tersebut. Perusahaan dengan penjualan yang stabil dapat lebih banyak mengambil hutang dan dapat menanggung biaya tetap yang tinggi dibandingkan perusahaan yang penjualannya tidak stabil.

Struktur aset merupakan proporsi atau rasio antara aset tetap terhadap total aset. Total aset adalah jumlah semua aset perusahaan terdiri dari aset tetap, aset lancar dan aset lainnya yang nilainya seimbang antara total kewajiban dengan ekuitas (Margaretha 2003, 108).
Struktur aset merupakan salah satu faktor penting dalam struktur modal atau keputusan pembiayaan perusahaan, karena jika perusahaan sedang mengalami kesulitan dalam membayar hutang, aset perusahaan dapat digunakan sebagai jaminan yang dapat mengurangi risiko kebangkrutan perusahaan.

Pertumbuhan aset merupakan selisih antara jumlah aset periode ini dengan periode sebelumnya dibandingkan dengan aset periode sebelumnya. Perusahaan yang memiliki tingkat pertumbuhan tinggi membutuhkan pendanaan yang lebih tinggi untuk ekspansi bisnis di masa depan. Perusahaan dengan tingkat pertumbuhan tinggi cenderung akan menggunakan hutang dibanding menggunakan ekuitas (Brigham dan Houston 1996, 39) dalam Darya dan Maesroh (2016).

Berbagai penelitian telah dilakukan mengenai struktur modal, namun demikian terdapat perbedaan hasil penelitian mengenai variabel independen berpengaruh positif, negatif, ataupun tidak berpengaruh terhadap variabel dependen. Kesenjangan tersebut di atas yang akan dibuktikan dalam penelitian ini.

Berdasarkan research gap pada hasil penelitianpenelitian sebelumnya, maka penelitian ini perlu dikaji kembali untuk memperjelas temuan selanjutnya. Peneliti tertarik untuk meneliti kembali Faktor-Faktor yang Mempengaruhi Struktur Modal pada Sektor Perkebunan Periode 2008-2016.

\section{METODE PENELITIAN}

Penelitian ini merupakan penelitian kasual. Penelitian kasual merupakan penelitian yang menunjukkan arah hubungan sebab akibat antara variabel independen dengan variabel dependen (Sugiyono 2014, 56). Penelitian ini dilakukan bertujuan untuk menjelaskan pengaruh variabel independen berupa profitabilitas, ukuran perusahaan, likuiditas, risiko bisnis, pertumbuhan penjualan, struktur aset dan pertumbuhan aset terhadap struktur 
modal sebagai variabel dependen pada perusahaan perkebunan yang terdaftar di Bursa Efek Indonesia periode 2008-2016.

Metode pengambilan sampel menggunakan metode purposive sampling, yaitu teknik sampling yang termasuk dalam non-probability sampling dimana tidak semua unsur atau anggota populasi mendapatkan kesempatan yang sama untuk diambil menjadi sampel, dalam teknik purposive sampling ini penentuan sampel berdasarkan kriteria atau pertimbangan tertentu (Sugiyono 2014, 122). Adapun kriteria pengambilan sampel dalam penelitian ini adalah sebagai berikut:

1. Perusahaan dalam industri perkebunan yang terdaftar di Bursa Efek Indonesia periode 2008-2016.

2. Perusahaan dalam industri perkebunan yang mempublikasi laporan keuangan tahunan per 31 Desember dari tahun 2008-2016.

3. Perusahaan harus menggunakan satuan nilai mata uang Rupiah.

Hasil pemilihan sampel dapat dilihat pada tabel 1 berikut ini:

Tabel 1 Pemilihan Sampel Penelitian

\begin{tabular}{lc}
\hline \multicolumn{1}{c}{ Kriteria Pemilihan Sampel } & Jumlah \\
\hline $\begin{array}{l}\text { Perusahaan sektor perkebunan yang terdaftar di BEl selama periode } \\
\text { 2008-2016 }\end{array}$ & 10 \\
$\begin{array}{l}\text { Perusahaan yang tidak memiliki laporan keuangan per 31 Desember } \\
\text { selama periode 2008-2016 }\end{array}$ & 0 \\
$\begin{array}{l}\text { Perusahaan yang tidak menggunakan mata uang rupiah dalam } \\
\text { laporan keuangan }\end{array}$ & 0 \\
Data outlier & $(2)$ \\
Jumlah perusahaan yang terpilih menjadi sampel & 8 \\
Periode penelitian 2008-2016 & 9 tahun \\
Jumlah data yang dijadikan sampel & 72 data \\
\hline
\end{tabular}

Struktur modal merupakan perbandingan atau imbangan antara total hutang dengan total ekuitas yang dimiliki oleh perusahaan. Struktur modal diukur dengan Debt Equity Ratio dengan menggunakan rumus sebagai berikut (Juliantika dan Dewi 2016):

\section{Debt Equity Ratio (DER)}

$$
=\frac{\text { Total Liabilities }}{\text { Total Equity }}
$$

Profitabilitas merupakan kemampuan perusahaan untuk menghasilkan keuntungan atau laba dari aktivitas operasional dalam suatu periode tertentu (Joni 2010). Profitabilitas diukur dengan Return on Assets dengan menggunakan rumus sebagai berikut (Juliantika dan Dewi 2016):

$$
\text { Return on Assets }=\frac{\text { Net Income }}{\text { Total Assets }}
$$

Ukuran perusahaan merupakan skala perusahaan yang dapat dilihat dari total aset perusahaan pada akhir tahun, dimana menggambarkan besar kecilnya sebuah perusahaan. Ukuran perusahaan dapat diukur dengan menggunakan rumus sebagai berikut (Juliantika dan Dewi 2016):

Ukuran Perusahaan

$$
=\operatorname{Ln}(\text { Total Assets) }
$$

Likuiditas merupakan kemampuan perusahaan untuk memenuhi kewajiban atau hutang yang segera harus dibayar dengan harta lancarnya. Likuiditas diukur dengan Current 
Ratio dengan menggunakan rumus sebagai berikut (Juliantika dan Dewi 2016):

$$
\text { Current Rasio }=\frac{\text { Current Assets }}{\text { Current Liabilities }}
$$

Risiko bisnis merupakan salah satu risiko yang dihadapi oleh perusahaan ketika menjalankan kegiatan operasinya, yaitu kemungkinan ketidakmampuan perusahaan untuk membiayai kegiatan operasionalnya. Risiko bisnis diukur dengan Degree of Operating Leverage dengan menggunakan rumus sebagai berikut (Juliantika dan Dewi 2016):

Degree of Operating Leverage

$$
=\frac{\% \text { Perubahan EBIT }}{\% \text { Perubahan Sales }}
$$

Pertumbuhan penjualan adalah tingkat hasil kinerja perusahaan di satu periode tertentu dalam bentuk penambahan atau pengurangan total penjualan. Kemudian, periode sebelumnya dapat dijadikan prediksi pertumbuhan untuk periode selanjutnya. Pertumbuhan penjualan dapat diukur dengan menggunakan rumus sebagai berikut (Darya dan Maesroh 2016):

Pertumbuhan Penjualan

$$
=\frac{\text { Total Sales } t-\text { Total Sales } t-1}{\text { Total Sales } t-1}
$$

Struktur aset adalah proporsi perbandingan antara aset tetap dengan total aset yang dimilki oleh suatu perusahaan. Struktur aset dapat diukur dengan menggunakan rumus sebagai berikut (Darya dan Maesroh 2016):

$$
\text { Struktur Aset }=\frac{\text { Fixed Assets }}{\text { Total Assets }}
$$

Pertumbuhan aset adalah tingkat perubahan antara jumlah aset periode tahun ini dengan periode sebelumnya dibandingkan dengan aset periode sebelumnya. Pertumbuhan aset dapat diukur dengan menggunakan rumus sebagai berikut (Darya dan Maesroh 2016):

Pertumbuhan Aset

$$
=\frac{\text { Total Assets } t-\text { Total Assets } t-1}{\text { Total Assets } t-1}
$$

\section{HASIL PENELITIAN}

Hasil statistika deskriptif dan pengujian hipotesis dapat dilihat pada tabel 2 dan tabel 3 berikut:

Tabel 2 Statisktik Deskriptif

\begin{tabular}{lllllllll}
\hline & DER & ROA & SIZE & CR & DOLL & GS & SA & GA \\
\hline Mean & 1.203371 & 0.067116 & 29.49082 & 1.234585 & -1.484258 & 0.267865 & 0.235869 & 0.198435 \\
Median & 1.099937 & 0.060461 & 29.48171 & 1.106529 & 0.970816 & 0.090290 & 0.201715 & 0.160934 \\
Maximum & 3.080163 & 0.403543 & 31.11342 & 5.219328 & 9.139428 & 9.621489 & 0.539573 & 1.332815 \\
Minimum & 0.178132 & -0.436311 & 27.20890 & 0.294602 & -175.6566 & -0.891764 & 0.041834 & -0.285462 \\
Std. Dev. & 0.680122 & 0.094771 & 1.006732 & 0.731205 & 21.14825 & 1.163474 & 0.136093 & 0.220016 \\
Obs. & 72 & 72 & 72 & 72 & 72 & 72 & 72 & 72 \\
\hline
\end{tabular}


Tabel 3 Hasil Pengujian Hipotesis

\begin{tabular}{cccc}
\hline Variable & B & t-Statistic & Sig. \\
\hline C & 8.351146 & 4.740190 & 0.0000 \\
ROA & -4.737991 & -5.921062 & 0.0000 \\
SIZE & -0.236581 & -3.880154 & 0.0003 \\
CR & -0.525388 & -6.688550 & 0.0000 \\
DOLL & 0.007745 & 2.514960 & 0.0148 \\
GS & -0.026876 & -0.612085 & 0.5430 \\
SA & 3.204722 & 7.690584 & 0.0000 \\
GA & 0.295488 & 1.205181 & 0.2332 \\
\hline
\end{tabular}

Profitabilitas memiliki nilai t-statistik sebesar -5.921062 lebih kecil dari t-tabel $1.99773(-5.921062<-1.99773)$ Hasil ini di dukung oleh nilai probabilitas sebesar $0.0000<$ 0.05 sehingga didapat kesimpulan bahwa terdapat pengaruh profitabilitas terhadap struktur modal.

Ukuran perusahaan memiliki nilai tstatistik sebesar -3.880154 lebih kecil dari nilai ttabel $-1.99773(-3.880154<-1.99773)$. Hasil ini didukung oleh nilai probabilitas 0.0003 , dimana lebih kecil dari a $0.05(0.0003<0.05)$ sehingga didapat kesimpulan bahwa terdapat pengaruh ukuran perusahaan terhadap struktur modal.

Likuiditas memiliki nilai t-statistik sebesar -6.688550 lebih kecil dari nilai t-tabel $1.99773(-6.688550<-1.99773)$. Hasil ini didukung oleh nilai probabilitas sebesar 0.0000 , dimana kecil besar dari a $0.05(0.0000<0.05)$ sehingga didapat kesimpulan bahwa terdapat pengaruh likuiditas terhadap struktur modal.

Risiko bisnis memiliki nilai t-statistik sebesar 2.514960 lebih besar dari nilai t-tabel 1.99773 (2.514960> 1.99773). Hasil ini didukung oleh nilai probabilitas sebesar 0.0148 dimana lebih kecil dari a $0.05(0.0148<0.05)$ sehingga didapat kesimpulan bahwa terdapat pengaruh risiko bisnis terhadap struktur modal.

Pertumbuhan penjualan memiliki nilai nilai t-statistik sebesar -0.612085 lebih besar dari nilai t-tabel $-1.99773 \quad(-0.612085>$ 1.99773). Hasil ini didukung oleh nilai probabilitas sebesar 0.5430 dimana lebih besar dari a $0.05(0.5430>0.05)$ sehingga didapat kesimpulan bahwa tidak terdapat pengaruh pertumbuhan penjualan terhadap struktur modal.

Struktur aset memiliki nilai t-statistik sebesar 7.690584 lebih besar dari nilai t-tabel 1.99773 (7.690584 > 1.99773). Hasil ini didukung oleh nilai probabilitas sebesar 0.0000 dimana lebih kecil dari a $0.05(0.0000<0.05)$ sehingga didapat kesimpulan bahwa terdapat pengaruh struktur aset terhadap struktur modal.

Pertumbuhan aset memiliki nilai tstatistik sebesar 1.205181 lebih kecil dari nilai ttabel 1.99773 (1.205181 < 1.99773). Hasil ini didukung oleh nilai probabilitas sebesar 0.2332 dimana lebih besar dari a $0.05(0.2332>0.05)$ sehingga didapat kesimpulan bahwa tidak terdapat pengaruh pertumbuhan aset terhadap struktur modal.

\section{PENUTUP}

Berdasarkan hasil penelitian dapat diperoleh kesimpulan bahwa profitabilitas, ukuran perusahaan, likuiditas, risiko bisnis dan struktur aset berpengaruh terhadap struktur modal. Sedangkan pertumbuhan penjualan dan pertumbuhan aset tidak berpengaruh terhadap struktur modal. Dalam penelitian ini terdapat keterbatasan yang mungkin berpengaruh terhadap hasil penelitian, yaitu (1) Penelitian ini hanya mencakup objek perusahaan perkebunan; (2) Penelitian ini hanya menggunakan variabel profitabilitas, ukuran perusahaan, likuiditas, risiko bisnis, 
pertumbuhan penjualan, struktur aset dan pertumbuhan aset, sementara masih terdapat variabel-variabel lain yang dapat mempengaruhi struktur modal; (3) Penelitian ini hanya mencakup periode selama 9 tahun yaitu tahun 2008-2016. Rekomendasi yang dapat dilakukan untuk penelitian selanjutnya adalah (1) Menggunakan objek penelitian yang lebih luas sehingga sampel dapat mewakili populasi, misalnya industri manufaktur atau industri non keuangan; (2) Menggunakan atau menambahkan variabel-variabel independen lainnya yang tidak terdapat dalam model yang mungkin dapat turut mempengaruhi struktur modal, contohnya non debt tax shield, pajak, dan variabel lainnya; (3) Menggunakan periode yang lebih lama misalnya sepuluh tahun sehingga menghasilkan jumlah sampel yang lebih banyak.

\section{REFERENCES:}

Ahmed, Naveed, Zulfiqar Ahmed, and Ishaq Ahmed. 2010. Determinant of Capital Structure: A Case of Life Insurance Sector of Pakistan. European Journal of Economic, Finance, and Administrative Sciences. 24 (24), $1-6$

Alzomaia, Turki SF. 2014. Capital Structure Determinants of Publicly Listed Companies in Saudi Arabia. Scholalry Journals. 8. 53-67

Brigham, Eugene F. dan Joel F. Houston. 2011. Essentials Of Financial Management, Third Edition. Singapore: Cengage Learning Asia Pte.

Brigham, Eugene F. dan Joel F. Houston. 2014. Essentials Of Financial Management, Third Edition. Singapore: Cengage Learning Asia Pte.

Cornett, Marcia Millon., Troy A. Adair Jr., dan John Nofsinger. 2015. Finance Application and Theory. United States of America: McGraw Hill.

Darya, I Gusti Putu dan Siti Maesroh. 2016. The Influence of Asset Structural, Growth Opportunity, Profitability and Sales Growth to Capital Sctructural in Consumer Goods Company Listed in IDX. IOSR Journal of Economics and Finance, 7(4) http://www.iosrjournals.org/iosr-jef/papers/Vol7-Issue4/Version1/D0704012939.pdf (diakses pada 19 Desember 2017).

Fauzi, Fitriya; Basyith, Abdul; Idris, Muhammad. 2013. The Determinants of Capital Structure: an Empirical Study of New Zealand-Listed Firms. Scholarly Journals. 5.

Gitman, Lawrence J dan Chad J. Zutter. 2015. Principles of Managerial Finance, Fourteenth Edition. England: Pearson Education Limited.

Joni dan Lina. 2010. Faktor-Faktor Yang Mempengaruhi Struktur Modal. Jurnal Bisnis dan Akuntansi. 12(2).

Juliantika, Ni Luh Ayu Amanda Mas dan Made Rusmala Dewi S. 2016. Pengaruh Profitabilitas, Ukuran Perusahaan, Likuiditas, dan Risiko Bisnis Terhadap Struktur Modal pada Perusahaan Property dan Real Estate. EJurnal Manajemen Unud, 5, No.7 https://ojs.unud.ac.id/index.php/Manajemen/article/view/20968 (diakses pada 19 Desember 2017).

Memon, Fozia, Niaz Ahmed Bhutto dan Ghulam Abbas. 2012. Capital Structure and Firm Performance: a Case of Textile Sector of Pakistan. Asian Journal of Business and Management Sciences, 1(9), (09-15)

Parlak, Deniz, 2010. Determinants of Capital Structure Policies of Turkish Manufacturing Firms. Scholarly Journals, 14

Sabir, Mahvish dan Qaisar Ali Malik. 2012. Determinants of Capital Structure - A Study of Oil and Gas Sector of Pakistan. Interdisciplinary Journal of Contemporary Research in Business. 3(10).

Saleem, FAiza, Bisma Rafique, Qaiser Mehmood, Muhamad Irfan, RAbia Saleem, Sidra Tariq dan Ghazala Akram. 2013. The Determinant of Capital Structure of Oil and Gas Firms Listed on Karachi Stock Exchange in Pakistan. Interdisciplinary Journal of Contemporary Research in Business. 4(9) 
Salehi, Mahdi; Manesh, Nazanin Bashiri. 2012. A Study of the Roles of Firm and Country on specific Determinants in Capital Structure: Iranian Evidence. Scholarly Journals.8.

Sartono, Agus R. 2001. Manajemen Keuangan Teori Dan Aplikasi. Yogyakarta: BPFE UGM.

Seftianne dan Handayani, Ratih. 2011. Faktor-faktor yang Mempengaruhi Struktur Modal pada Perusahaam Publik Sektor Manufaktur. Jurnal Bisnis dan Akuntansi. 13 (1), 39-56

Sugiyono. 2014. Metode Penelitian Kuantitatif Kualitatif dan R\&D. Bandung: Alfabeta.

Umer, Usman Muhammed. 2014. Determinants of Capital Structure: Empirical Evidence from Large Taxpayer Share Companies in Ethiopia. Scholarly Journals. 6, 53-55. 
